EESTI NSV TEADUSTE AKADEEMIA TOIMETISED. 29. KOIDE GEOLOOGIA. 1980, NR. 1

ИЗВЕСТИЯ АКАДЕМИИ НАУК ЭСТОНСКОИ ССР. ТОМ 29 ГЕОЛОГИЯ, 1980, № 1

\title{
КОНТАКТ ОРДОВИКА И ДЕВОНА В ЮГО-ВОСТОЧНОЙ ЭСТОНИИ
}

Седиментационные перерывы, занимающие значительную часть геологического прошлого (Наливкин, 1974), часто неуловимы в конкретных разрезах. Изучая терригенные отложения, мы порой даже не знаем, сколько в них имеется перерывов осадконакопления. Большие седиментационные перерывы обычно четкие, особенно когда отсутствуют целые системы или отделы. Но бывают и исключения. В Юго-Восточной Эстонии, где отсутствуют часть ордовика, вся силурийская система и почти весь нижний отдел девонской системы, иногда трудно провести границу между ордовиком и девоном. Это связано с литологической и минералогической близостью ордовикских и девонских отложений на данной территории, особенно в случаях, когда пиргуские отложения верхнего ордовика покрыты резекненскими отложениями среднего девона. Пограничные слои ордовика и девона в Юго-Восточной Эстонии представлены часто литологически близкими сероцветными песчано-алевритовыми карбонатными породами.

Выяснение характера рассматриваемой границы важно для правильной стратификации. Однако больший интерес представляет изучение ее как случая скрытого перерыва. С этой целью в Юго-Восточной Эстонии в шести скважинах детально исследовались пограничные ордовикскодевонские отложения (рис. 1). В четырех скважинах пиргуские отложения ордовика надстилаются резекненскими отложениями девона (Кавасту, Мехикоорма, Райгла, Пылва), в одной - вормсиские отложения ордовика - тильжескими отложениями девона (Вярска) и в одной азериские отложения ордовика - тильжескими (?) девона (Хино).

Отложения верхов пиргуского горизонта (скв. Пылва, Кавасту, Мехикоорма, Райгла) в этом районе представлены тонко- и среднеслоистыми, в разной степени глинистыми (местами алевритистыми) доломитизированными известняками и доломитами, где прослоями встречаются доломитизированные мергели. Содержание мелкого полидетрита обычно минимальное (в пределах $2-5 \%$ ). Породы преобладающе сероцветные с желтыми гетитизированными пятнами, образованными в результате разложения пирита (скв. Кавасту), реже с фиолетовыми и красновато-коричневыми пятнами и разводами (скв. Кавасту, Пылва). Макроскопически выветрелый облик имеют породы верхов $(0,4$ м) пиргуского горизонта в скв. Кавасту. Содержание карбонатного компонента колеблется в пределах $46-92 \%$. Количество песчано-алевритового терригенного материала больше на севере региона. Так, в скважинах Кавасту и Мехикоорма он составляет обычно $20-59 \%$, а в скважинах Райгла и Пылва $14-24 \%$ нерастворимого остатка пород. При этом сильно преобладает мелкоалевритовая $(0,01-0,05$ мм) фракция. Пес- 


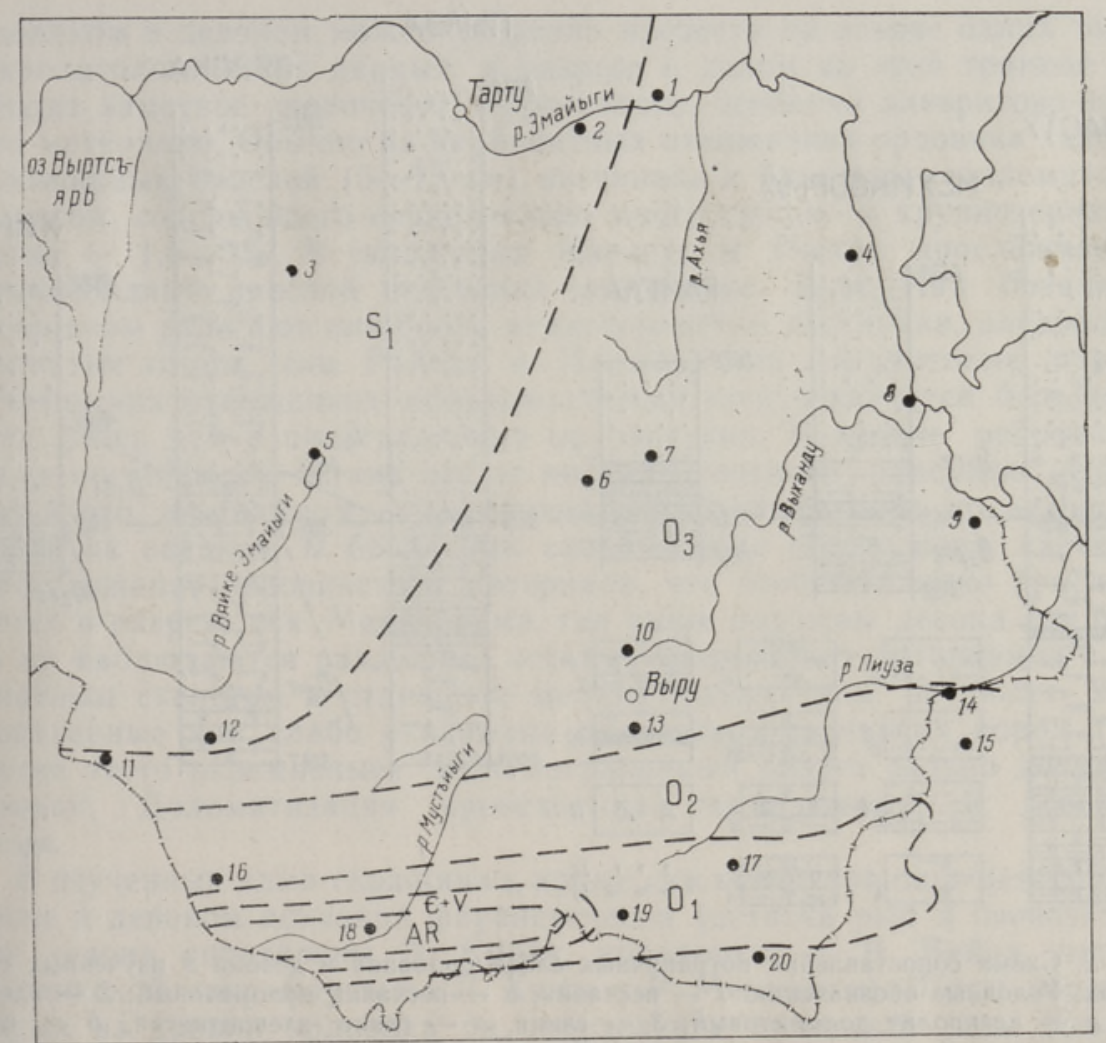

Рис. 1. Схема выходов додевонских пород Юго-Восточной Эстонии. Буровые скважины: 1 - Кавасту, 2 - Каагвере, 3 - Элва, 4 - Мехикоорма, 5 - Отепя, 6 - Киома, 7 - Пылва, 8 - Райгла, 9 - Вярска, 10 - Вяймела, 11 - Валга, 12 - Карула, 13 - Выру (Кубия), 14 - Петсери, 15 Декшино, 16 - Лаанеметса, 17 - Тсийстре, 18 - Мынисте, 19 - Луутснику, 20 - Хино.

чаные $(0,1-1,0$ мм $)$ и крупноалевритовые $(0,05-0,1$ мм $)$ частицы суммарно составляют обычно менее $1 \%$, кроме образцов из скв. Кавасту, в которых крупноалевритовых частиц было $2-6 \%$ и в одном образце даже почти $25 \%$.

Отложения вормсиского горизонта (скв. Вярска) представлены среднеслоистыми до массивных, доломитизированными мергелями с прослоями карбонатных глин зеленовато-серого цвета и с красноватокоричневыми, розовыми и фиолетовыми пятнами и разводами. В породах присутствуют очень редкий и мелкий полидетрит и единичные зерна глауконита. Нижняя часть вормсиского горизонта более карбонатная. Песчано-алевритовые частицы составляют $3-11 \%$ нерастворимого остатка. Преобладает мелкоалевритовая фракция. Крупноалевритовых и песчаных частиц содержится соответственно до 1,8 и 2,3\%.

Азериские отложения, подстилающие девонские в скв. Хино, представлены средне- и тонкослоистыми среднеглинистыми доломитизированными известняками с разнозернистым полидетритом. Породы красновато-коричневого цвета с зеленовато-серыми пятнами и разводами. Песчано-алевритовых частиц в нерастворимом остатке $1,6 \%$.

Девонские отложения резекненокого возраста в рассматриваемом районе представлены переслаивающимся комплексом серых алевролитов 


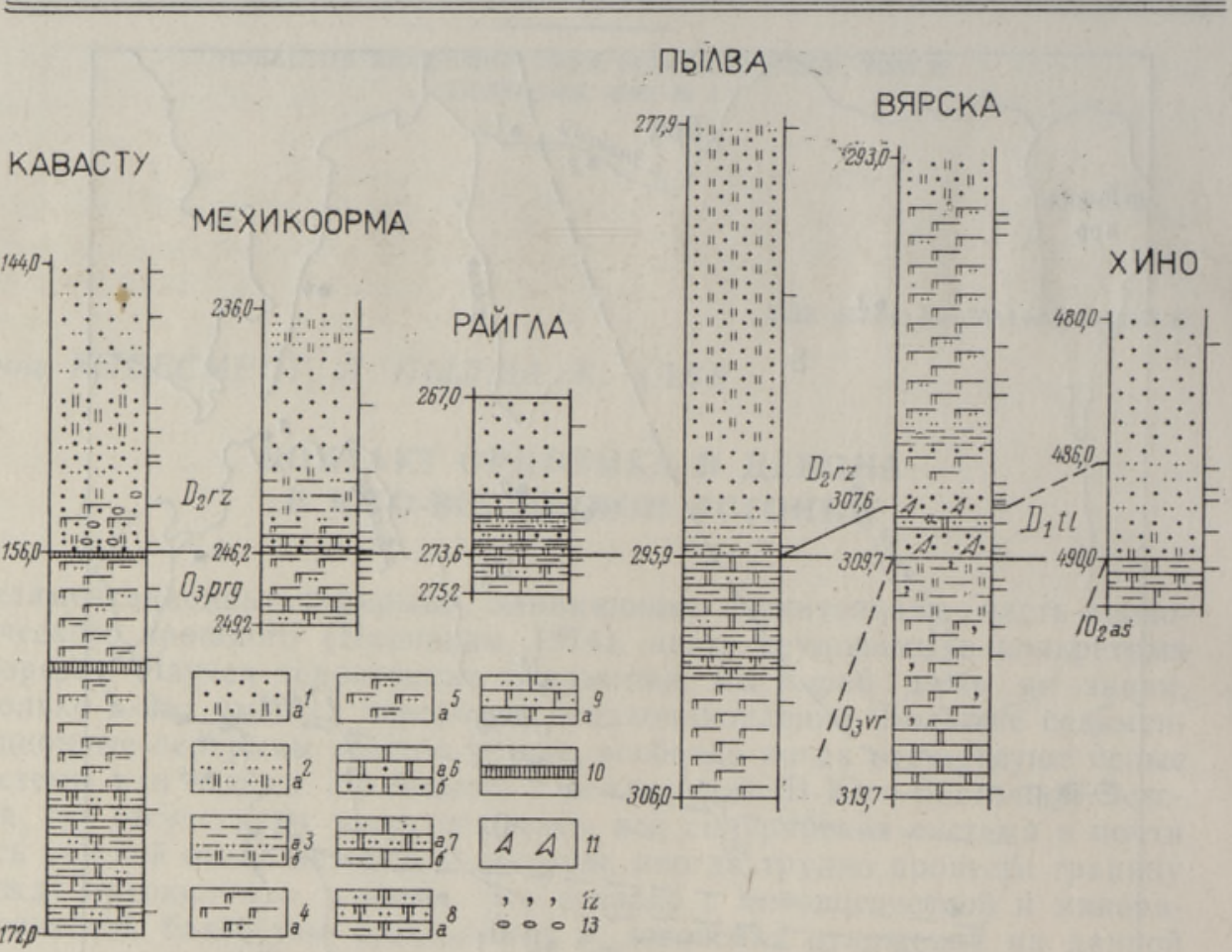

Рис. 2. Схема сопоставления пограничных слоев ордовика и девона в изученных скважинах. Условные обозначения: 1 - песчаник, $a$ - песчаник доломитовый; 2 - алевролит, $a$ - алевролит доломитовый; 3 - глина, $a$ - глина алевритистая, $б-$ глина доломитистая; 4 - домерит доломит९вый, $a$ - домерит доломитовый, песчанистый; 5 - домерит доломитовый, алевритистый, $a$ - домерит доломитовый, глинистый; 6 доломит, $a-$ доломит песчанистый, 6 - доломит песчаный; 7 - доломит алевритистый, $a$ - доломит алевритовый, б- доломит глинистый; 8 - известняк доломитовый, алевритистый, $a$ - известняк доломитовый, глинистый; 9 - известняк доломитистый, $a$ - известняк доломитистый, глинистый; 10 - метабентонит; 11 - гипсовый цемент песчаников; 12 - глауконит; 13 - псефитовый материал.

Места взятия образцов отмечены с правой стороны колонок. Горизонты: $\mathrm{O}_{2} \mathrm{as}-$ aзериский, $\mathrm{O}_{3} \mathrm{vr}$ - вормсиский, $\mathrm{O}_{3} \mathrm{prg}$ - пиргуский, $\mathrm{D}_{1} \mathrm{tl}$ - тильжеский, $\mathrm{D}_{2} \mathrm{rz}$ резекненский.

и песчаников, содержащим прослои домеритов, доломитов и глин (Клеесмент и др., 1975). Нижние $10-15$ м разреза преимущественно доломитизированы - алевролиты и песчаники имеют главным образом базальный доломитовый цемент. Обычно доломитовая часть занимает $20-60 \%$ слагающих здесь пород. Особенно сильно доломитизированы нижние 1,6-5,0 м комплекса, где доломитовый компонент всегда составляет $40-60 \%$ породы. В южной части исследуемого района (скв. Райгла и Пылва) в низах резекненского горизонта наблюдается прослой темно-коричневой алевритовой сланцевой бескарбонатной или слабо карбонатной глины мощностью $0,2-0,3 \mu$, который является хорошим маркирующим уровнем (рис. 2). Девонские отложения тильжеского возраста, занимающие нижние 2 м девонского разреза в скв. Вярска, представлены мелко- и среднезернистыми розовыми песчаниками с гипсово-доломитовым цементом. Обнаружен также прослой белого доломита мощностью $0,5 \mathrm{M}$ (рис. 2). В кровле ордовика гипс встречается только в трещинах и кавернах. В скв. Хино низы девона представлены песчано-алевритовыми породами серого и фиолетового цвета.

Если разрезы данного района изучить детально, то границу между 
ордовиком и девоном можно уверенно провести на основе одних только макролитологических данных: в разрезе в целом на этой границе происходит заметное увеличение терригенного, особенно алевритово-песчаного материала. Обычно на карбонатных отложениях ордовика залегает маломощный прослой $(5-15$ cм) песчаника с базальным доломитовым цементом, содержащего сравнительно много средне- и крупнозернистых частиц - 1,5-5\%. В скважинах Кавасту и Пылва прослежнвается брекчиевидный прослой песчаника мощностью $5 \mathrm{~cm}$. Над базальным песчаником залегают или более мелкозернистые песчаники, алевролиты, плитчатые глины (скв. Райгла и Пылва), или доломитовые породы. В девонских отложениях макроскопически прослеживается больше чешуек слюд, чем в подстилающих ордовикских. В кровле ордовикских пород отсутствуют четкие следы континентального перерыва. Объясняется это, по-видимому, денудацией выветрелых пород до отложения девонских осадков. В базальных слоях девона обнаружено частичное переотложение ордовикского материала, что особенно четко прослеживается в разрезе скв. Мехикоорма, где выше подошвы девона (не более 0,5 м) наблюдаются различные остатки ордовикских организмов с карбонатным скелетом и отдельные мелкие (диаметром не более 2 cм) неокатанные или слабо окатанные обломки ордовикских пород (те и другие часто окремнелые). Весь пограничный разрез сильно доломитизирован. Доломитизация происходила, по-видимому, в девонское время.

В изученных нами скважинах, кроме скв. Хино, граница между ордовиком и девоном доказана фаунистически (остатки рыб и беспозвоночных девона определены Э. Курик, конодонты - В. Вийра, остатки ордовикской макрофауны - Л. Хинтс и Р. Мяннилем). Шесть образцов, взятых из кровли ордовика на определение хитинозой (скв. Кавасту, Райгла, Мехикоорма), по данным Я. Нылвака, оказались без фауны.

В керне скв. Кавасту на глубине 157,0 м обнаружены фрагменты беззамковых брахиопод и сколекодонты (?). На глубине 156,7 м обнаружены Dianulites sp. и Ptilodictya sp., а также обломки трилобитов, мшанок, криноидей и водорослей, указывающие на верхнеордовикский возраст этих слоев. На глубине 155,7 м найдены остатки ископаемых организмов девонского возраста - чешуи акантод типа Acanthodes и туберкулы артродир (?).

В скв. Мехикоорма фаунистически хорошо охарактеризованы как верхи ордовика, так и низы девона (Клеесмент и др., 1975). Самый верхний палеонтологически охарактеризованный уровень ордовика 246,3 м - содержит конодонты Ambalodus triangularis, Amorphognathus sp., Ligonodina delicata, Tetraprioniodus superbus, Oistodus excelsus, Scolopodus insculptus, Coelocerodontus sp., Panderodus sp. Самый нижний фаунистически доказанный девонский уровень - 246,1 м, где найдены Acanthodii (чешуи типа Diplacanthus), Crossopterygii (чешуи типа Onychodus) и отолиты, указывающие на резекненский возраст среднего девона. Смешанная ордовикско-девонская фауна найдена в скв. Мехикоорма на глубине 245,3 м, где наряду с чешуями девонских акантод встречаются окатанные членики стебля криноидеи.

В скв. Райгла на глубине 273,8 м обнаружены конодонты верхнего ордовика Belodina cf. compressa, Roundya diminuta, Ambalodus triangularis, Amorphognathus sp., Oistodus venustus, Panderodus sp., Drepanodus sp. На глубине 272,2 м определены фоссилии девонского возраста Acanthodii (чешуи типа Acanthodes), Arthrodira n. gen. (крыша черепа и эндокраний), Lingula sp., остракоды и гастроподы.

В скв. Пылва на глубине 302,0 м определены конодонты Icriodus? 
$\frac{\sqrt{8}}{3}$

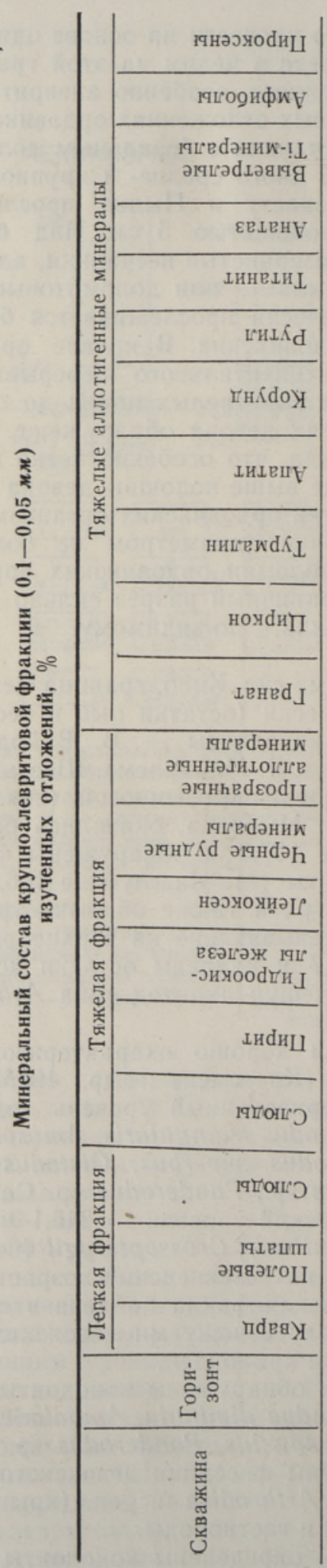

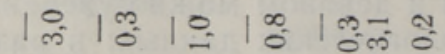

ํํㅇำ

분



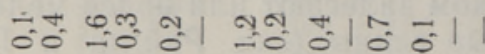

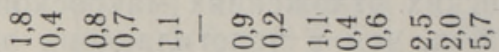

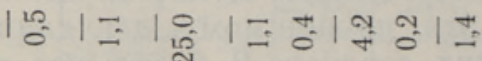

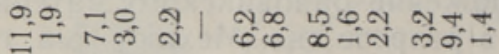

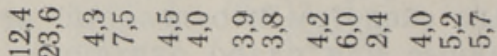

क은 ปัป

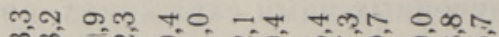

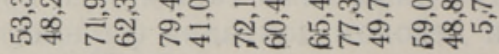
$O N=$ ขูO $\forall$ त



TN N

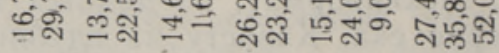

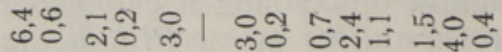

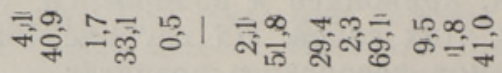

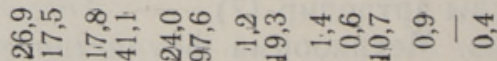

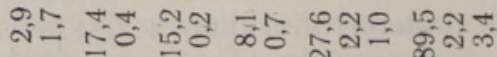

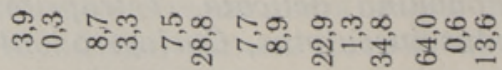

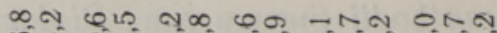
๒ี

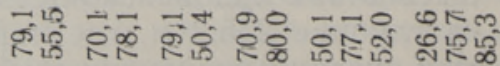
जo

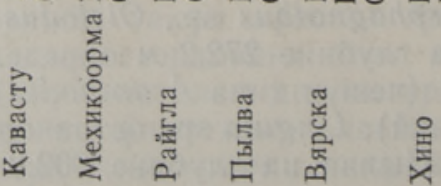


sp., Panderodus sp., Roundya? sp., Oneotodus sp., похожие на ордовикские. На глубине 300,6 м найдены окремнелые фрагменты мшанок, трилобитов и иглокожих. На глубине $295,5-295,8$ м обнаружена девонская фауна: чешуи акантод, обломки пластинок артродир и фрагменты беззамковых брахиопод.

В скв. Вярска на глубине 312,0 м определены конодонты верхнего ордовика Acodus similaris, Belodina cf. compressa, Keislognathus gracilis, Tetraprioniodus cf. superbus, Ambalodus triangularis, Amorphognathus sp., Panderodus sp. На глубине 311,2 и 310,5 м найдены только фрагменты конодонтов и беззамковых брахиопод. На глубине $309,0-309,5$ м В. Талимаа определила телодонты тильжеского возраста нижнего девона Turinia pagei, Turinia sp., Nikolivia gutta, N. elogata. На глубине 307,3 и 301,0 м обнаружены чешуи акантод резекненского возраста.

Минеральный состав пограничных отложений ордовика и девона в изученном районе довольно близок. Особенно это касается легкой фракции, которая во всех встречаемых здесь стратиграфических единицах в преобладающем большинстве случаев представлена полевошпатовокварцевым составом с содержанием в крупноалевритовой фракции $50-80 \%$ кварца и $15-30 \%$ полевых шпатов. Однако следует отметить, что в ордовикских отложениях среди полевых шпатов плагиоклазы играют более значительную роль, чем в девонских. Породы, легкая фракция которых обогащена слюдистыми минералами, редки, но встречаются они как в ордовике, так и в девоне (табл. 1).

Тяжелые минералы крупноалевритовой фракции в ордовикских и девонских породах различаются прежде всего соотношением аутигенных и аллотигенных минералов. В ордовикских отложениях основную часть тяжелой фракции составляют аутигенные минералы, в частностц пирит и гидроокислы железа. Из тяжелых минералов существенную часть образуют черные рудные минералы, среди которых преобладает магнетит. В тяжелой фракции девонских отложений в большинстве случаев преобладают аллотигенные минералы, особенно прозрачные (табл. 1). Однако следует иметь в виду, что и в карбонатных отложениях девона пирит и гидроокислы железа подчас составляют более $90 \%$ фракции. Соотношения прозрачных аллотигенных тяжелых минералов, имеющие среди других минералогических признаков наибольшее значение для стратиграфии (Клеесмент, 1976), в вормсиских, пиргуских, тильжеских и резекненских отложениях изученного района весьма близки. Минералогические различия между ордовиком и девоном устанавливаются здесь главным образом по сопутствующим минералам. Среди прозрачных аллотигенных тяжелых минералов в этих горизонтах в ЮгоВосточной Эстонии преобладает гранат, на втором месте стоит циркон (табл. 1). В вормсиских и пиргуских отложениях помимо граната и циркона в значительных количествах встречаются амфиболы, пироксены и корунд. В пиргуских отложениях (например, в скв. Мехикоорма и Райгла) часто наблюдается довольно высокое содержание турмалина. В тильжеских отложениях кроме граната и циркона в значительных количествах обнаружен только апатит. В резекненских отложениях циркон-гранатовая ассоциация сопровождается турмалином и апатитом, в то время как остальные прозрачные аллотигенные минералы встречаются здесь в ничтожных количествах (табл. 1). В группе прозрачных аллотигенных тяжелых минералов азериских отложений сильно преобладает циркон, сопровождаемый титанистыми минералами, турмалином и гранатом (табл. 1).

Типоморфные особенности главных аллотигенных минералов ордовикских и девонских пород также имеют много общих черт, однако 
Таблица 2

Некоторые типоморфные особенности турмалина

\begin{tabular}{|c|c|c|c|c|c|c|c|c|c|}
\hline \multirow[b]{2}{*}{$\begin{array}{c}\text { Гори- } \\
\text { зонт }\end{array}$} & \multicolumn{9}{|c|}{ Количество зерен, \% } \\
\hline & $\begin{array}{c}\text { Ока- } \\
\text { танных }\end{array}$ & $\begin{array}{c}\text { Изо- } \\
\text { метрич- } \\
\text { ных }\end{array}$ & $\begin{array}{l}\text { Зеле- } \\
\text { ных }\end{array}$ & $\begin{array}{l}\text { Корич- } \\
\text { невых }\end{array}$ & $\begin{array}{l}\text { Зеле- } \\
\text { ных } \\
\text { до ро- } \\
\text { зовых }\end{array}$ & $\begin{array}{l}\text { Си- } \\
\text { них }\end{array}$ & $\begin{array}{c}\text { С вклю- } \\
\text { чения- } \\
\text { ми }\end{array}$ & $\begin{array}{c}\text { С много- } \\
\text { числен- } \\
\text { ными } \\
\text { включе- } \\
\text { ниями }\end{array}$ & $\begin{array}{l}\text { Разло- } \\
\text { женных }\end{array}$ \\
\hline $\mathrm{D}_{2} \mathrm{rz}$ & 47 & 90 & 63 & 23 & 12 & 2 & 35 & 20 & 8 \\
\hline $\mathrm{O}_{3}$ & 78 & 94 & 59 & 31 & 6 & 4 & 33 & 24 & 5 \\
\hline
\end{tabular}

Таблица 3

Некоторые типоморфные особенности циркона

\begin{tabular}{|c|c|c|c|c|c|c|c|c|c|}
\hline \multirow[b]{2}{*}{$\begin{array}{l}\text { Гори- } \\
\text { зонт }\end{array}$} & \multicolumn{9}{|c|}{ Количество зерен, \% } \\
\hline & $\begin{array}{c}\text { Ока- } \\
\text { танных }\end{array}$ & $\begin{array}{l}\text { Изо- } \\
\text { метрич- } \\
\text { ных }\end{array}$ & $\begin{array}{l}\text { Корич- } \\
\text { невых }\end{array}$ & $\begin{array}{l}\text { Розо- } \\
\text { вых }\end{array}$ & $\begin{array}{l}\text { Жел- } \\
\text { тых }\end{array}$ & $\begin{array}{c}\text { Зональ- } \\
\text { ных }\end{array}$ & $\begin{array}{c}\text { С вклю- } \\
\text { чения- } \\
\text { ми }\end{array}$ & $\begin{array}{c}\text { Pac- } \\
\text { трес- } \\
\text { канных }\end{array}$ & $\begin{array}{l}\text { Загряз- } \\
\text { ненных }\end{array}$ \\
\hline $\mathrm{D}_{2} \mathrm{rz}$ & 77 & 93 & 9 & 3 & 7 & 11 & 51 & 27 & 10 \\
\hline $\mathrm{O}_{3}$ & 80 & 95 & 8 & 3 & 8 & 9 & 47 & 27 & 10 . \\
\hline
\end{tabular}

существует и ряд стратиграфически важных различий. Характерно, что в девонских отложениях кварц имеет больше кристаллических включений и чаще отличается нарушенным погасанием, чем в ордовикских отложениях. Закономерно, что и гранат в девонских отложениях имеет больше включений $(45-60 \%)$, чем в ордовикских $(20-40 \%)$. Стратиграфически важны также повышенные содержания удлиненных и плеохроирующих от зеленого до розового турмалинов в девонских и коричневых и синих турмалинов в ордовикских отложениях (табл. 2). Количества циркона в рассматриваемых двух системах мало различаются. Можно отметить лишь очень незначительное увеличение содержания коричневых цирконов в девонских отложениях, что, однако, в средних цифрах отражается слабо (табл. 3 ).

Нами изучались также изменения минералов в пограничных отложениях. Аллотигенные минералы ордовикских карбонатных пород явными признаками выветривания не обладают. Зона повышенного содержания гидроокислов железа обычно занимает только несколько десятков сантиметров верхов ордовикских пород. Исключение составляют вормсиские отложения в скв. Вярска, где повышенное содержание гидроокислов железа наблюдается в верхних 4 м. В этой части разреза отмечено также относительно высокое содержание желтых гранатов.

Аллотигенные минералы, встречающиеся в девонских отложениях надконтактовой части разреза, имеют более явные признаки выветривания. В этих породах чаще встречаются измененные, мутные по краям зерна турмалина и турмалины, имеющие многочисленные, ориентированные в одном направлении включения. Количество зерен турмалина, плеохронрующих от зеленого до розового, также довольно большое. Можно предполагать, что все названные признаки турмалина взанмосвязаны и указывают на происхождение этого минерала из выветрелых додевонских пород. В надконтактовых породах девона встречается также много загрязненных, мутных зерен граната, циркона и апатита, а 
кроме того, зерен апатита, имеющих регенерационные каемки. Показатель преломления у таких зерен апатита часто ниже обычного. Для надконтактовых отложений характерны также выделения титанистых минералов на полевых шпатах и слюдистых минералах.

Как следует из сказанного, в литологически довольно однородном разрезе пограничных слоев ордовика и девона в Юго-Восточной Эстонии границу между этими системами можно однозначно провести только на основе фаунистических данных. При отсутствии же палеонтологического материала для точного проведения этой границы существенное значение имеют различные описанные выше литологические и минералогические критерии.

При изучении терригенно-карбонатного разреза пограничных слоев ордовика и девона в Юго-Восточной Эстонии особое внимание следует обратить на то, что выветрелый материал прослеживается здесь только в переотложенном виде в надконтактовой части разреза, а в подконтактовой части ордовика следы выветривания практически отсутствуют, т. е. они уничтожены додевонской денудацией. Подтверждается это наличием переотложенных остатков ордовикской фауны в базальной части девона. Такое явление, по-видимому, широко распространено в терригенно-карбонатных и карбонатных отложениях, и его нельзя оставлять без внимания, особенно при изучении немых нли палеонтологически плохо охарактеризованных толщ.

\section{ЛИТЕРАТ У РА}

Клеесмент А. О принципах корреляции разрезов на основе минералогических показателей (на примере палеозойских терригенных отложений Прибалтики). В кн.: Методика и ннтерпретация результатов минералогических и геохимических исследований. Вильнюс, 1976, 44-52.

Клеесмент А. Э., М арк-Курик Э. Ю., Каратаюте-Талимаа В. Н, $\mathrm{B}$ а й тек унен е Г. К., К а я к К. Ф. Древнейшие отложения среднего девона Эстонии. - В кн.: Геология кристаллического фундамента и осадочного чехла Прибалтики. Рига, $1975,168-183$.

Нал и в и н Д. В. Проблемы перерывов. - В кн.: Этюды по стратиграфии. М., 1974, $10-21$.

\section{Институт геологии \\ Академии наук Эстонской ССР \\ Поступнла в редакцию 7/VI 1979}

управление геологии СМ Эстонской ССР

Anne KLEESMENT, L. POLMA, K. KAJAK

\section{ORDOVIITSIUMI JA DEVONI KONTAKT KAGU-EESTIS}

Valdaval osal Kagu-Eesti territooriumist lasuvad devoni setted ordoviitsiumi kivimite kulumispinnal. Nende ladestute litoloogiline ilme on kontaktilähedases osas küllaltki sarnane, esinevad hallid liivakas-aleuriitsed karbonaatkivimid. Käesoieva tööga seoses uuriti kuues puursüdamikus kontaktilähedaste ordoviitsiumi ja devoni kivimite litoloogilisi ja mineraloogilisi erinevusi. Ilmnes, et porsunud materjal esineb nendes läbilōigetes ainult ümbersettinuna devoni basaalses osas, kuna ordoviitsiumi kivimite kontaktilähedases osas porsumisilmingud praktiliselt puuduvad — nad on hävinud devonieelse kulutuse tagajärjel. Sellele nähtusele tuleks tähelepanu pöörata ka teiste analoogiliste terrigeen-karbonaatsete või karbonaatsete, ulatusliku settelüngaga läbilōigete uurimisel. 
Anne KLEESMENT, L. POLMA, K. KAJAK

\section{CONTACT BETWEEN THE ORDOVICIAN AND DEVONIAN IN SOUTH-EAST ESTONIA}

In most of the territory of South-East Estonia Devonian rocks occur on the denudated surface of the Ordovician ones. Near the boundary, the rocks of these two systems are very similar, represented by grey-coloured sandy aleuritic carbonates. In six cores lithological and mineralogical differences of near-boundary Ordovician and Devonian rocks have been studied. It becomes evident that the weathered material in these sections is only redeposited in the lowermost part of Devonian beds, but in the uppermost part of Ordovician rocks there is no evidence of weathering these were destroyed by a Pre-Devonian denudation. This phenomenon must also be taken into account when investigating analogous terrigenous carbonates or carbonate sections with extensive sedimentary discontinuity. 